\title{
Pancreatic Cancer Associated Fibroblasts (CAF): Under-Explored Target for Pancreatic Cancer Treatment
}

\author{
Jeffrey Norton ${ }^{1,2, *}$, Deshka Foster ${ }^{1,2}$, Malini Chinta ${ }^{1}$, Ashley Titan ${ }^{1,2}$ and Michael Longaker ${ }^{1,2,3}$ \\ 1 Hagey Laboratory for Pediatric Regenerative Medicine, Division of Plastic and Reconstructive Surgery, \\ Stanford University School of Medicine, Stanford, CA 94305, USA; dsfoster@stanford.edu (D.F.); \\ mchinta@stanford.edu (M.C.); atitan@stanford.edu (A.T.); longaker@stanford.edu (M.L.) \\ 2 Division of General Surgery, Department of Surgery, Stanford University School of Medicine, Stanford, \\ CA 94305, USA \\ 3 Institute for Stem Cell Biology and Regenerative Medicine, Stanford University School of Medicine, Stanford, \\ CA 94305, USA \\ * Correspondence: janorton@stanford.edu
}

Received: 31 March 2020; Accepted: 19 May 2020; Published: 25 May 2020

\begin{abstract}
Pancreatic cancer is the 4th leading cause of cancer deaths in the United States. The pancreatic cancer phenotype is primarily a consequence of oncogenes disturbing the resident pancreas parenchymal cell repair program. Many solid tumor types including pancreatic cancer have severe tumor fibrosis called desmoplasia. Desmoplastic stroma is coopted by the tumor as a support structure and CAFs aid in tumor growth, invasion, and metastases. This stroma is caused by cancer associated fibroblasts (CAFs), which lay down extensive connective tissue in and around the tumor cells. CAFs represent a heterogeneous population of cells that produce various paracrine molecules such as transforming growth factor-beta (TGF-beta) and platelet derived growth factors (PDGFs) that aid tumor growth, local invasion, and development of metastases. The hard, fibrotic shell of desmoplasia serves as a barrier to the infiltration of both chemo- and immunotherapy drugs and host immune cells to the tumor. Although there have been recent improvements in chemotherapy and surgical techniques for management of pancreatic cancer, the majority of patients will die from this disease. Therefore, new treatment strategies are clearly needed. CAFs represent an under-explored potential therapeutic target. This paper discusses what we know about the role of CAFs in pancreatic cancer cell growth, invasion, and metastases. Additionally, we present different strategies that are being and could be explored as anti-CAF treatments for pancreatic cancer.
\end{abstract}

Keywords: cancer associated fibroblast (CAF); pancreatic ductal adenocarcinoma (PDAC)

\section{Background}

Progress in the treatment of pancreatic cancer remains slow and tedious. Despite substantial investment in time and resources, the prognosis of patients with pancreatic cancer, primarily pancreatic ductal adenocarcinoma (PDAC), is still poor. In the United States approximately 56,770 patients will be diagnosed with pancreatic cancer each year and 45,750 (80\%) will die from it. It is the 4 th leading cause of cancer death in both men and women in the world. The most recent American Cancer Society database reports that the 5-year survival of all patients with pancreatic cancer is $9 \%$. If the cancer is diagnosed early enough for the patient to undergo surgery to remove the tumor, the 5-year survival is still only $34 \%$ [1]. Therefore, new treatments and new treatment strategies are clearly needed to improve the outcome of patients with this devastating disease. 
The pancreatic cancer phenotype is primarily a consequence of oncogenes disturbing the resident pancreas parenchymal cell repair program [2]. The major genes that are mutated in association with pancreatic cancer are KRAS, p16/CDKN2, TP53, and SMAD4/DPC4. BRCA1 and -2 are also associated with an increased risk of pancreatic cancer. The pancreatic cancer milieu consists of transformed cancer cells in various stages of epithelial mesenchymal transition (EMT) and non-transformed stroma. This stroma is composed predominantly of cancer associated fibroblasts (CAFs), as well as macrophages, immune cells, endothelial cells, and epithelial cells $[3,4]$. The microenvironment plays an important role in influencing tumor progression and prognosis. Each cell type interacts with the transformed cancer cells, and as such is a potential target for treatment. The characteristic desmoplastic stroma contributes greatly to the challenges of treating pancreatic cancer; it has been shown in multiple studies to be involved in many aspects of tumor pathogenesis including the promotion of tumor progression, invasion, metastasis, and chemoresistance [5]. EMT is a process of cellular plasticity that contributes to cancer cell invasion and metastasis [6]. CAFs are key players in cancer cell EMT. In a recent study, loss of E-cadherin in tumor buds, increased expression of vimentin, and activation of CAFs, all signs consistent with cancer cell EMT, were associated with more aggressive tumors requiring portal vein resection and an increased probability of positive resection margins [7]. This complexity suggests that an improved understanding of the molecular basis of cell-cell interaction in the cancer stroma is required to effectively target cancer specific growth mechanisms [8,9].

The non-transformed fibroblasts that are both within and surrounding pancreatic cancers are not passive bystanders but rather constitute a complex, active environment (Figure 1) with clear roles in tumor growth and dissemination [10]. CAFs of the pancreatic tumor microenvironment have been shown to enact a dysregulated wound healing response [11] and curiously, have been found to play both tumor-supportive and tumor-suppressive roles [11,12]. The pancreatic CAFs cause fibrosis and desmoplasia that can affect the ability of surgery to excise the tumor and chemotherapy/immunotherapy drugs to eradicate the tumor. Fibrosis induces a firmness and stickiness of the tumor, making it adherent to critical structures and more tedious and challenging to achieve complete tumor excision that is documented pathologically by negative margins. Negative margins at surgery is currently the best chance to cure this disease. Chemotherapy treatment shortcomings have been previously attributed to the desmoplastic stroma. The theory is that CAFs cause desmoplasia that results in decreased microvascularity causing inability of the chemotherapy drugs to effectively penetrate into the tumor [13]. Further complicating this, some studies have shown that the presence of certain sub-types of CAFs are associated with more aggressive tumors and shorter survival suggesting that there is fibroblast heterogeneity in the context of pancreatic cancer and that all CAFs are not the same and do not function in the exact same manner [14].

If we consider all patients who present with pancreatic cancer, nearly two-thirds have distant metastases or locally advanced disease at the time of diagnosis making surgery impossible and upfront chemotherapy critical. However, if we convert locally-advanced pancreatic cancer to completely resectable cancer with preoperative chemotherapy, the long-term survival rate is similar to patients who present with resectable tumors [15]. Chemotherapy unlike radiation therapy does not make the surgery more difficult; therefore, improved chemotherapy regimens are very much needed. Gemcitabine, the long-time drug of choice for pancreatic cancer, only has a response rate of $23 \%$ and when given to patients with distant metastases the median survival is only 6 months. An example of anti-fibroblast treatment that has already been shown to improve outcome is (nab)-paclitaxel when it is administered with gemcitabine. When (nab)-paclitaxel is added to gemcitabine, the median survival increases to 9 months. $(\mathrm{Nab})$-paclitaxel decreases the CAF content in the tumor resulting in a marked alteration of tumor stroma and tissue softening resulting in better penetration of gemcitabine into the tumor cells [16]. Such findings suggest that strategies to affect CAFs may improve outcome of patients with pancreatic cancer and support the use of anti-stromal therapies alongside conventional chemotherapies. The current most effective chemotherapy regimen is FOLFIRINOX which is a combination of leucovorin, 5-fluorouracil, irinotecan, and oxaliplatin. It has a partial response rate of nearly $80 \%[17,18]$. This regimen has been 
able to convert some locally advanced tumors to surgically resectable $[15,18]$. However, it is more toxic than other regimens and as such, cannot be used in older patients with poor performance status. Clearly additional improvements in systemic therapy for pancreatic cancer are needed, and the use of anti-stromal strategies may be an effective supporting strategy.

CAFs are the subject of this review and represent an underutilized treatment target in pancreatic cancer. Although some clinical trials and ongoing animal studies are exploring modalities to target CAFs therapeutically [19-23], this area has yet to be fully developed. This paper aims to provide an update on the progress made in understanding pancreas CAFs and their role in stromal formation, cancer progression, invasion, and metastases. We will review mechanisms of stromal influence on pancreatic cancer, chemoresistance, and potential of anti-CAF therapy to improve outcomes.

\section{CAFs and Tumor Stroma/Extracellular Matrix}

Pancreatic cancers are composed of extracellular matrix and various cell types including transformed cancer cells, fibroblasts, endothelial cells, pericytes, macrophages, and a host of other immune cells. Activated CAFs are among the most abundant cell type, comprising between $15-85 \%$ of the stromal cells $[24,25]$. The definition of a cancer associated fibroblast (CAF) is not straight forward [19]. The difficulty comes from a lack of specific cell surface markers that are expressed only on cancer associated fibroblasts and not other cell types. Because of this, CAFs are usually identified by cell morphology, tissue position and lack of lineage markers for other cell types such as epithelial cells, endothelial cells and leukocytes. Expression of vimentin and platelet-derived growth factor receptor- $\alpha$ (PDGFR $\alpha$ ) are commonly used as markers for fibroblasts when combined with other criteria like spindle cell shape and tissue location. Other markers for activated fibroblasts also exist, including $\alpha$-smooth muscle actin ( $\alpha \mathrm{SMA}$ ) and fibroblast activation protein (FAP) $[19,26]$. Activated fibroblasts may also express podoplanin, fibroblast specific protein-1 (FSP-1), transforming growth factor-beta (TGF-beta), and platelet derived growth factor receptor-beta (PDGFR-beta) $[27,28]$

CAFs are densely arranged around all cancerous structures as a complete or incomplete ring [5]. Equivalent fibroblasts are not present around benign ducts and other tissue. CAFs present specific activated myoblast-like characteristics such as cellular elongation with pseudopods. TGF-beta (Table 1) has been shown to increase cell stiffness of both normal fibroblasts and CAFs; it also increases CAFs elongation and spreading, which is not seen in standard non-activated fibroblasts. It also enhances CAF invasion in tumor stroma [29]. 
Table 1. Cancer associated fibroblasts (CAFs) play a central role in the multistep processes of tumor initiation, progression, invasion, and metastases.

\begin{tabular}{|c|c|c|c|c|}
\hline Molecule & Source Cell & Target Cell & Effect & Reference \\
\hline Annexin A6 & CAFs & Cancer cells & $\begin{array}{l}\text { CAF derived annexin A6+ extracellular vesicles } \\
\text { found to support pancreatic cancer aggressiveness }\end{array}$ & Leca et al., J Clin Invest, 2016 [30] \\
\hline CXCL12 & CAFs & Cancer cells & Effector of immunosuppression by $\mathrm{FAP}+\mathrm{CAFs}$ & Feig et al., Proc Natl Acad Sci, 2013 [31] \\
\hline Collagen & CAFs & Cancer cells & $\begin{array}{l}\text { Well aligned collagen in the stroma is associated } \\
\text { with worse prognosis }\end{array}$ & Drifka et al., Oncotarget, 2016 [32] \\
\hline Asporin & $\begin{array}{l}\text { Activated pancreatic } \\
\text { stellate cells, CAFs }\end{array}$ & Cancer cells & $\begin{array}{l}\text { Enhances EMT, promotes cancer cell invasion } \\
\text { and metastases }\end{array}$ & Wang et al., Cancer Lett, 2017 [33] \\
\hline TGF-B & CAFs, Cancer cells & $\begin{array}{l}\text { CAFs, Cancer cells, } \\
\text { CD8 T-cells }\end{array}$ & $\begin{array}{l}\text { Increases CAF stiffness and elongation } \\
\text { Suppresses CD8 T cell acquisition to the tumor as } \\
\text { well as function }\end{array}$ & $\begin{array}{l}\text { Stylianou et al., Biochim Biophys Acta } \\
\text { Gen Subj, 2018 [29] } \\
\text { Ahmadzadeh \& Rosenberg, J Immunol, } \\
2005 \text { [34] }\end{array}$ \\
\hline $\begin{array}{l}\text { MAPK, STAT3 } \\
\text { signaling }\end{array}$ & CAFs & Cancer cells & $\begin{array}{l}\text { Paracrine CAF TGF-B promotes MAPK and STAT3 } \\
\text { signaling, which causes EMT and enhanced } \\
\text { PDAC proliferation }\end{array}$ & Ligorio et al., Cell, 2019 [35] \\
\hline Il-8 & Senescent CAFs & Cancer cells & Prometastatic phenotype & Wang et al., 2017. [36] \\
\hline Big-h3 & CAFs & Tumor CD8+ T-cells & $\begin{array}{l}\text { Inhibits tumor specific CD8 T-cells and increases } \\
\text { tumor growth }\end{array}$ & Goehrig et al., Gut, 2019 [37] \\
\hline FAP & CAFs & Cancer cells & $\begin{array}{l}\text { Cancer cell motility, invasiveness and progression. } \\
\text { Also, tumor angiogenesis and ECM deposition. }\end{array}$ & $\begin{array}{l}\text { Kawase et al., BCM Gastroenterol, } \\
2015 \text { [38] }\end{array}$ \\
\hline Podoplanin & CAFs & Cancer Cells & Worse outcome & $\begin{array}{l}\text { Hu et al., Cell Physiol Biochem, } \\
2018 \text { [39] }\end{array}$ \\
\hline Il-6 & CAFs & Cancer cells & Survivin (apoptosis inhibitor) expression & Duluc et al., EMBO Mol Med, 2015 [40] \\
\hline VEGF & Pancreatic stellate cells & Tumor stroma & Angiogenesis & $\begin{array}{l}\text { Masamune et al., Am J Physiol } \\
\text { Gastrointest Liver Physiol, } 2008 \text { [41] }\end{array}$ \\
\hline SDF-1 & CAFs & Cancer cells & Tumor progression and resistance to gemcitabine & Wei et al., Cell Death Dis, 2018 [42] \\
\hline $\begin{array}{l}\text { Thymic stromal } \\
\text { lymphopoietin (TSLP) }\end{array}$ & $\begin{array}{l}\text { CAFs, simulated by } \\
\text { cancer cell Il-1 }\end{array}$ & Immune cells & Development of Th2 immunity, worse survival & $\begin{array}{l}\text { Brunetto et al., J Immunother Cancer, } \\
2019 \text { [43] }\end{array}$ \\
\hline
\end{tabular}


CAFs are known to generate dense fibrosis or desmoplasia within and around the tumor. A significant proportion of pancreas tumor stroma is composed of various collagen patterns, composing the desmoplasia (Figure 1). Changes in stromal collagen alignment have been shown to modulate cancer cell behavior and have prognostic significance [32]. Highly aligned collagen occurs in $12 \%$ of patients with pancreatic cancer and portends an especially poor prognosis [32]. Patients with highly aligned collagen specifically do worse following surgical resection than those whose tumors do not have this characteristic. Tumor associated collagen signature-3 (TACS-3) is characterized by bundles straightened and aligned collagen fibers that are perpendicular to the tumor boundary. TACS-3 is associated with poor disease-free and overall survival in breast cancer [44].
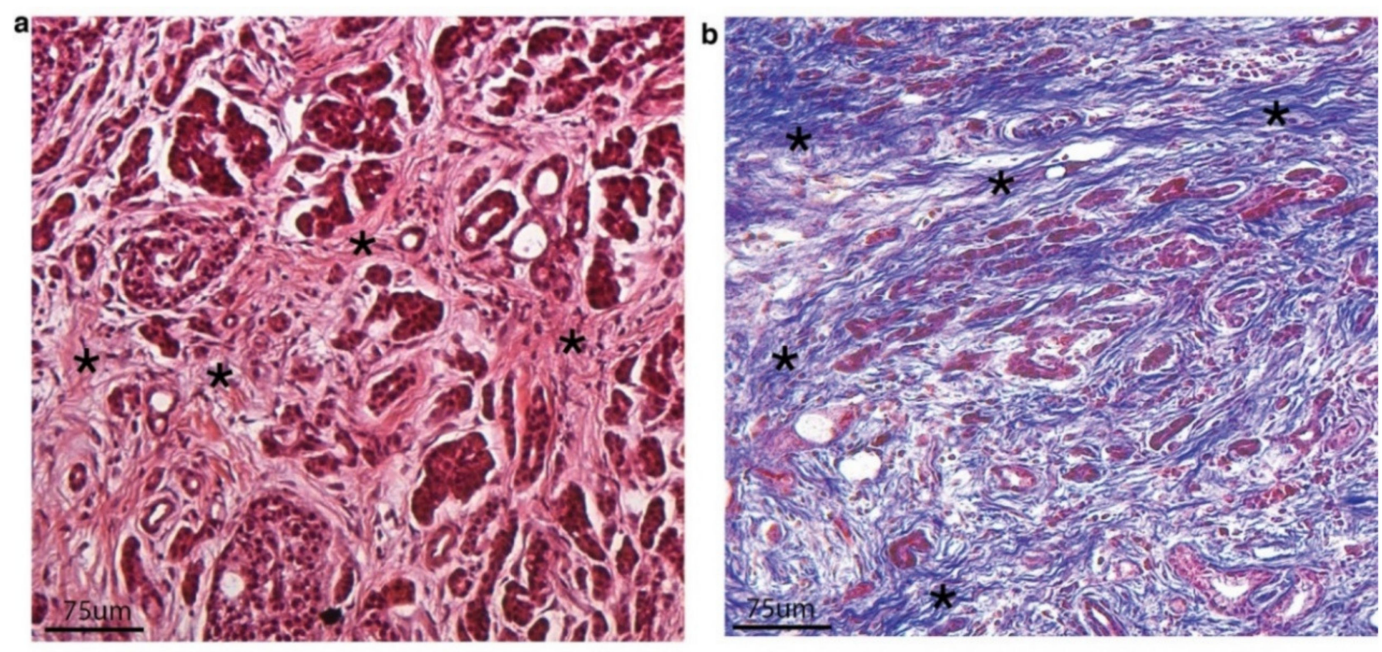

Figure 1. (a) Hematoxylin and Eosin (H\&E stain) of a surgically resected pancreatic ductal adenocarcinoma showing small and medium glands with irregular morphology embedded in dense, desmoplastic stroma (highlighted with black asterisks). (b) Trichrome stain of surgically resected pancreatic ductal adenocarcinoma highlighting severe desmoplasia and dense matrix that appears as linearized ribbons of blue stain (collagen fibers) (highlighted with black asterisks).

Epigenetic mechanisms (primarily DNA methylation) have been found to regulate genes involved in the formation of extracellular matrix, most commonly hyaluronan. Hyaluronan is an abundant extracellular matrix component in pancreatic cancer and is a marker of poor prognosis. Pancreatic cancer cells can reprogram stromal cells through DNA methylation of genes by direct contact. CAFs actively remodel the desmoplastic stroma by (1) secreting matricellular proteins like hyaluronic acid, collagens, and tenascin C, (2) inducing cross linking of collagen 1 via expression of lysyl oxidase, and (3) secreting metalloproteinases that degrade the matrix. The binding of extracellular matrix proteins (ECM) to integrin receptors on non-tumor cells (immune cells and bone marrow derived dendritic cells) facilitates their recruitment to the ECM and the interaction of the ECM with tumor cells facilitates metastases. CAFs are also known to be highly chemotherapy resistant [45]. High levels of IL-6 correlate with chemoresistance [45,46]. Further, a dense desmoplastic ECM increases interstitial fluid pressure and acts as a barrier to drug delivery, leading to poor accumulation of chemotherapy in tumor resulting in a lack of efficacy.

\section{PDAC CAF Heterogeneity}

CAFs constitute a diverse cell population that is difficult to define as no specific cell surface marker exists, but which is known to consist of several cell subtypes [19] (COX2). In human and mouse pancreatic cancer studies, Tuveson's group has shown the presence of unique subpopulations of CAFs: Myofibroblastic CAFs (myCAFs) that secrete trophic factors and extracellular matrix components to construct the extracellular matrix and inflammatory CAFs (iCAFs) that secrete Il-6 and use an IL-1 
induced signaling cascade that leads to JAK/STAT activation and promotes an inflammatory CAF state $[47,48]$.

CAFs are known to be heterogeneous in pancreatic cancer $[35,49,50]$. Such heterogeneity exists with regards to cell surface marker expression, cytokine production, cell signaling, cell-cell interactions, and gene expression. This heterogeneity explains why one type of CAF is found to support cancer invasiveness and metastases while another type does not [51]. Single cell technology is being used to delineate CAF heterogeneity in pancreatic cancer, but the exact spatial distribution and forces that drive single-cell phenotypes have not been well described. Using single cell RNA and protein kinetic studies to examine the role of CAFs in modulating heterogeneity of pancreatic cancer, a recent study identifies a shift toward EMT, and fibroblast proliferation linked to mitogen-activated protein kinase (MAPK) and signal transducer and activator of transcription 3 (STAT3) signaling. This shows the impact of stroma in shaping tumor architecture by altering inherent patterns of tumor glands in pancreatic cancer.

Although CAFs are a highly heterogenous cell population they are generally identified as an alpha-SMA positive cell [35,38]. Other markers have been identified in CAFs and expression of each has been associated with an effect on prognosis. There is no one marker; however, that captures all pancreatic cancer CAFs [19]. The heterogeneity of pancreatic cancer CAFs is further supported by recent research that identified a subpopulation of stromal cells that was designated as cancer associated mesenchymal stem cells that caused cancer cell invasion through granulocyte-macrophage colony-stimulating factor (GM-CSF) in one study and increased tumor cellular proliferation and larger tumors in a second study $[5,52,53]$. GM-CSF appeared to cause these results by inducing down regulation of E-cadherin and up-regulation of TWIST1 and vimentin through the JAK2/STAT3 pathway [5,54]. The relationship between CAFs and these "cancer associated mesenchymal stem cells" has yet to be completely elucidated.

Previously described pathways involved in CAF activation include sonic hedgehog, TGF-beta, IL-1, IL-6, and IL-10 [29,43,55-59]. CAFs are also activated by growth factors and cytokines such as CCL2, PDGF, hepatocyte growth factor, and fibroblast growth factor (FGF) [60]. Once activated CAFs develop a contractile and secretory function, secreting many of the factors known to be further involved in their activation including IL-1 and IL-6 [56]. Some activated CAFs in pancreatic cancer express and secrete fibroblast activated protein (FAP), which influences cancer cell motility and invasion, cancer cell cycle progression, extracellular matrix deposition, and angiogenesis within the tumor matrix [38]. TGF-beta that has been linked to induction of EMT induces FAP expression. The intensity of FAP expression in pancreatic cancer correlates inversely with outcome such that higher expressing tumors have worse outcome [38]. Removing the CAFs expressing fibroblast activation protein (FAP), a protein that inhibits immune cell function, resulted in improved immune control over tumor growth and progression and uncovered the efficacy of immune modulating antibodies [61]. Blockade of FAP in combination with radiation treatment in murine models of pancreatic cancer was associated with antigenic specific tumor $\mathrm{T}$ cell infiltrate and enhanced collagen deposition but it did not prolong survival even when combined with anti-PD1 therapy [53]. FAP is also noted to allow pancreatic cancer cells to escape immune surveillance. FAP+ CAFs are the primary pancreatic cancer source of the chemokine ligand 12 (CXCL12). Administration of an inhibitor of chemokine receptor 4, a CXCL12 receptor ligand, resulted in synergizing anti-PD-L1 immunotherapy [31]. Pancreatic cancer immune evasion is well-described and is currently being extensively investigated. It may be overcome by enhancing $\mathrm{T}$ cell immune response. It has been shown that despite the presence of antitumor $\mathrm{T}$ cells, immunotherapeutic antibodies are ineffective in a murine pancreatic cancer model. Cancer immune suppression in pancreatic cancer appears to be mediated by CXCL 12, the chemokine that binds to cancer cells and excludes T cells by a mechanism that is dependent on the CXCL 12 receptor CXCR4 [31,62] (Table 1).

Some pancreatic CAF sub-populations are now known to have an inflammatory phenotype [28,47]. Podoplanin, a well conserved mucin-type transmembrane protein, exerts various functions including regulation of tissue development and cellular motility. Podoplanin + fibroblasts are recruited to the 
pancreas tumor microenvironment. Podoplanin+ fibroblast infiltration of pancreatic carcinoma is associated with worse overall and disease-free survival [39].

\section{CAFs and Tumor Progression}

CAFs and cytokines promote tumor progression. Both play a central role in tumor progression, invasion, and metastases and some fibroblast subtypes may play a role tumor initiation (Table 2). A recent study of the murine intestinal mesenchymal niche demonstrated that colorectal cancer initiation was orchestrated by a population of rare peri-cryptal prostaglandin E2 fibroblasts that exert paracrine control over tumor initiating stem cells [63].

Table 2. Primarily pancreatic ductal adenocarcinoma (PDAC) CAF subtypes and their characteristic markers and functions.

\begin{tabular}{|c|c|c|c|}
\hline PDAC CAF Sub-Type & Characteristics & Proposed Role & Reference \\
\hline $\begin{array}{l}\text { iCAF } \\
\text { (inflammatory CAF) }\end{array}$ & $\begin{array}{l}\text { Il- } 6^{\text {high }}, \text { aSMA } \\
\text { adjach, } \\
\text { adjacent to tumor cells }\end{array}$ & $\begin{array}{l}\text { Tumorigenesis and } \\
\text { cancer progression }\end{array}$ & $\begin{array}{l}\text { Ohund et al., JEM, } \\
2017 \text { [48] }\end{array}$ \\
\hline $\begin{array}{l}\text { myCAF } \\
\text { (myofibroblasts CAF) }\end{array}$ & $\begin{array}{l}\text { Il- } 6^{\text {low }} \text {, aSMA }{ }^{\text {low }} \text {, distant } \\
\text { from tumor cells }\end{array}$ & & $\begin{array}{l}\text { Ohund et al., JEM, } \\
2017 \text { [48] }\end{array}$ \\
\hline $\begin{array}{l}\text { apCAFs (antigen } \\
\text { presenting CAFs) }\end{array}$ & $\begin{array}{l}\text { Express CD74 and MHC } \\
\text { class II }\end{array}$ & Activate CD4 T-cells & $\begin{array}{l}\text { Elyada et al., Cancer } \\
\text { Discov, } 2019 \text { [64] }\end{array}$ \\
\hline $\mathrm{FAP}+\mathrm{CAFs}$ & Express FAP & $\begin{array}{l}\text { Escaping the immune } \\
\text { system (blocking of } \\
\text { CD8+ anti-tumor T cells) }\end{array}$ & $\begin{array}{l}\text { Zhang et al., Oncotarget, } \\
2016 \text { [65] }\end{array}$ \\
\hline CD10+GPR77+ CAFs & & $\begin{array}{l}\text { Enhances PDAC } \\
\text { cell invasion }\end{array}$ & Su et al., Cell, 2018 [66] \\
\hline Podoplanin+ CAFs & Express podoplanin & Worse prognosis & $\begin{array}{l}\text { Hu et al., Cell Physiol } \\
\text { Biochem, 2018. [39] }\end{array}$ \\
\hline $\begin{array}{l}\text { aSMA+ PDAC } \\
\text { myofibroblasts }\end{array}$ & Express aSMA & $\begin{array}{l}\text { Depletion of this } \\
\text { sub-type resulted in } \\
\text { more aggressive tumors } \\
\text { and decreased survival } \\
\text { in mice }\end{array}$ & $\begin{array}{l}\text { Ozdemir et al., Cancer } \\
\text { cell, } 2015 \text { [20] }\end{array}$ \\
\hline PDGFRa+ SAA1+ CAFs & $\begin{array}{l}\text { Express PDGFRa } \\
\text { and SAA1 }\end{array}$ & $\begin{array}{l}\text { Stimulate PDAC tumor } \\
\text { growth in mice }\end{array}$ & $\begin{array}{l}\text { Djurec et al., Proc Natl } \\
\text { Acad Sci, } 2018\end{array}$ \\
\hline "Sub-type A" & $\begin{array}{l}\text { aSMA }^{\text {low }}, \text { Vimentin } \\
\text { Prow } \\
\text { Proliferation }\end{array}$ & $\begin{array}{l}\text { "invasive front", } \\
\text { poor prognosis }\end{array}$ & $\begin{array}{l}\text { Neuzillet et al., J Pathol, } \\
2018 \text { [50] }\end{array}$ \\
\hline "Sub-type B" & $\begin{array}{l}\text { aSMA }^{\text {high }}, \text { Vimentin } \\
\text { Pigh } \\
\text { Proliferation }^{\text {low }}, \text { ECM+ }\end{array}$ & Intermediate prognosis & $\begin{array}{l}\text { Neuzillet et al., J Pathol, } \\
2018 \text { [50] }\end{array}$ \\
\hline "Sub-type C" & $\mathrm{ECM}+$, Immune++ & Good prognosis & $\begin{array}{l}\text { Neuzillet et al., J Pathol, } \\
2018 \text { [50] }\end{array}$ \\
\hline “Sub-type D" & $\begin{array}{l}\text { aSMA }^{\text {high }}, \text { Vimentin }^{\text {high }} \\
\text { Proliferation }^{\text {low }}, \text { ECM+ }\end{array}$ & Poor prognosis & $\begin{array}{l}\text { Neuzillet et al., J Pathol, } \\
2018 \text { [50] }\end{array}$ \\
\hline
\end{tabular}

CAFs secrete cytokines and growth factors that stimulate tumor growth. Thymic stromal lymphopoietin (TSLP), a key cytokine for the development of Th2 immunity, is produced by CAFs in pancreatic cancer. Tumor infiltration of Th2 cells is associated with decreased survival. Recent studies show that pancreatic tumor production of IL-1 alpha and beta is a stimulant for TSLP secretion by CAFs [43]. Some CAF-secreted factors are involved in cancer cell EMT. Experimental evidence has suggested a role for zinc finger E-box binding homeobox I (ZEB1) in EMT, invasion, and metastases in pancreatic cancer. ZEB1 expression is present in both cancer cells and fibroblasts. Fibroblast ZEB 1 expression is an independent predictor of survival after pancreatic cancer resection [67]. Asporin is 
another molecule that is highly expressed in CAFs. It is a mediator of pancreatic stem cell activation and EMT. It mediates invasion and migration of pancreatic cancer cells through both autocrine and paracrine mechanisms [33].

One mechanism by which tumors can recruit and activate fibroblasts is via exosomes [68]. Translocation via exosomes transfers metabolic substrates from CAFs to tumor cells. Exosomes from CAFs contain lactate, acetate, amino acids, lipids, and tricarboxylic acid cycle intermediates that are feeding tumor cells and reprograming them to inhibit mitochondrial oxidative phosphorylation and upregulate glycolysis that allows the cancer cells to grow in an anaerobic environment. Metabolic studies also show that CAF autophagy stimulated by pancreas tumor cells causes alanine secretion that out competes against glutamine for fuel for tumor cells in a low glucose environment. The transcription factor ETV1 doubled pancreatic cancer tumor volume in mice by stromal expansion, altered stromal morphology, increased tumor cell invasion, and upregulated EMT regulators including SLUG, SNAIL, TWIST, vimentin, ZEB1, ZEB2, and MMP9 [69]. A negative regulator of stromal formation, CD 146 or MCAM, has a critical role in tumor progression and invasion. CD 146 negative pancreatic cancer patients have higher grade tumors, more advanced clinical stage and a greater likelihood of postoperative residual cancer. CD 146 positive pancreatic cancer patients have increased survival compared to CD 146 negative patients. Knockout of CD 146 was found to enhance pancreatic cancer cell migration and invasion and induce pro-inflammatory genes SDF1A, CXCL1, CCL5, HGF, and COX2 [70].

\section{CAFS and PDAC Metastatic Spread}

The possible mechanisms by which CAFs can assist in metastases are multiple. CAFs can secrete cytokines and chemokines, as previously mentioned, that specifically support tumor progression. For example, the chemokine CCL5 which acts on cancer cells to promote invasion and metastases [71]. Senescent CAFs, which represent a subtype of CAFs, are known to secrete excess IL-8. IL-8 is a mediator of cancer cell CAF interaction and promotes pancreatic cancer cell invasion and metastasis [36]. Senescent CAFs are also known to inhibit the immune response to the tumor and to remodel extracellular matrix to allow cancer cells to invade. Finally data in human prostate and colon cancer, and a mouse model of lung metastases, suggests that CAFs can circulate in the blood to develop a niche to sustain small numbers of tumor cells that travel through the circulation to distant sites and facilitate tumor cell establishment there [72-74]. CAFs also play a pivotal role in inducing metastases by triggering EMT pathways in cancer cells and establishing metastatic niches (Figure 2). Ligorio and others used single cell RNA and protein analytics in a murine model of pancreatic cancer to identify single cell population shifts toward EMT and proliferation linked with MAPK and STAT 3 signaling [35]. Hypoxia marker carbonic anhydrase IX and the lactate transporter MCT 4 in the stroma is associated with EMT transfer and phenotype in pancreatic cancer cells and also portends shorter survival [75]. A recent study showed that portal vein invasion by pancreatic cancer was seen in tumors with loss of membranous E-cadherin in tumor buds, higher expression of vimentin, activated CAF morphology, and margin positive resection [7]. This study suggests that portal vein invasion is associated with aggressive tumor biology and disseminated tumor growth less amenable to margin negative surgical resection.

Malignant cells facilitate lung metastasis by bringing their own stromal components. In an experimental mouse model, the viability of circulating cancer cells was greater when they carried their own heterotopic stromal cell fragments. Moreover, when these circulating tumor cells with stromal components had the cancer associated fibroblasts depleted there was a significant decrease in the number of lung metastases and a prolongation of survival. This demonstrates the importance of CAFs in the development of metastases [36]. Further, stretching fibroblasts remodels fibronectin and enhances the ability of co-cultured cancer cells to migrate. Finally, stretching normal fibroblasts converts them to the phenotype of CAFs suggesting that mechanical stress is a critical factor in fibroblast activation [76]. Pancreatic cancer cell survival and metastases appears to be dependent on crosstalk that is mediated through extracellular vesicles. Formation of an ANXA6/LRP1/TSP1 complex was 
dependent on CAFs and required physiologic culture conditions that improved tumor cell survival and migration. Depletion of ANXA6 in CAFs results in impaired complex formation and subsequently impaired pancreatic cancer occurrence and metastases. This was reversed by injection of CAF derived ANXA6+ vesicles which enhanced tumorigenesis [77].

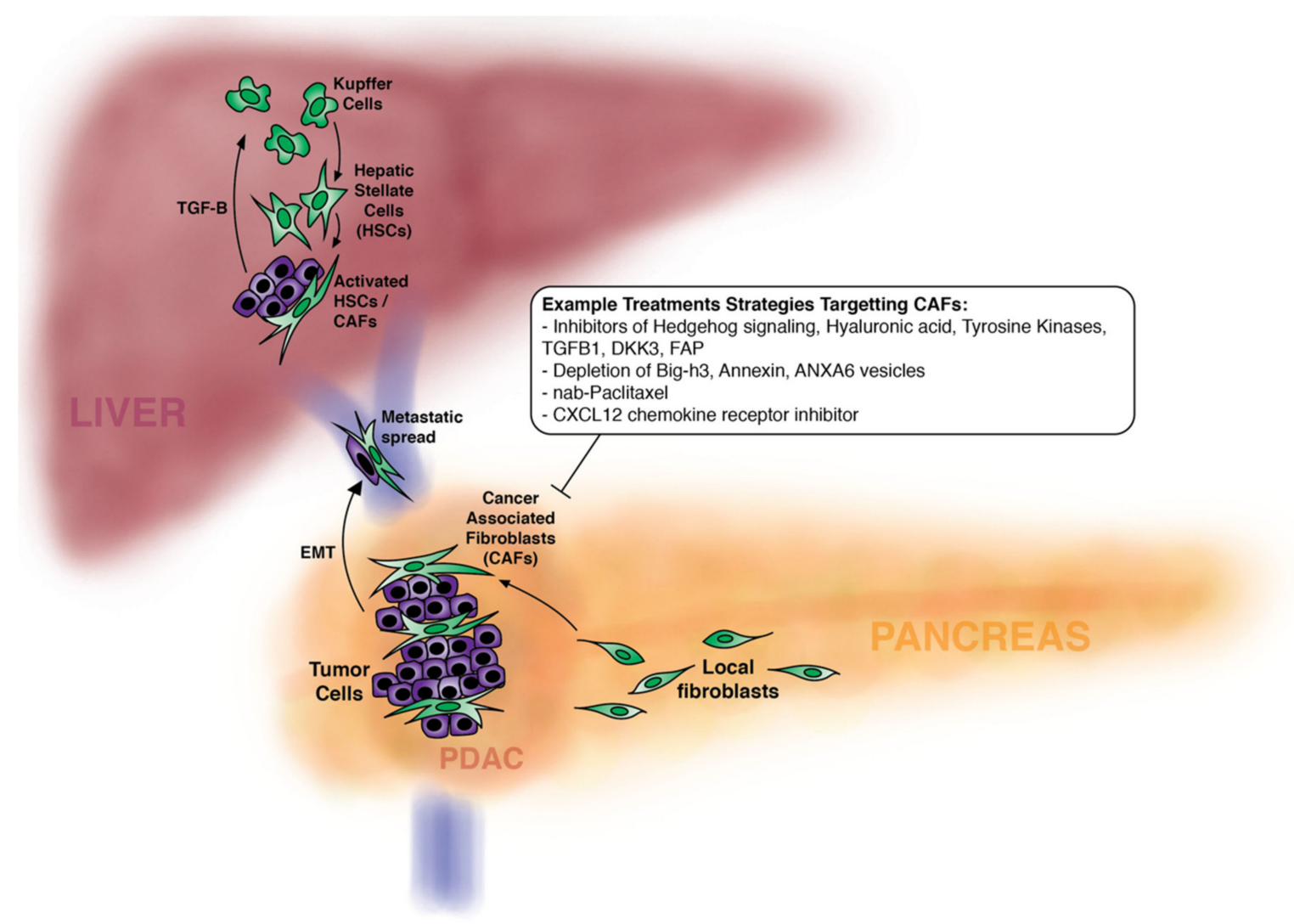

Figure 2. Primary pancreatic cancer recruits fibroblasts to become cancer associated fibroblasts (CAFs). Tumor cells with CAFs invade the portal vein and metastasize to the liver. In order to establish a focus in the liver, Kupffer cells secrete transforming growth factor-beta (TGF-beta) that recruits and activates hepatic stellate cells to become CAFs. Strategies to treat pancreatic cancer through CAFs include inhibitors of the hedgehog pathway, hyaluronidase, tyrosine kinase, and inhibitors of CAF recruitment. miRNAs are a potentially useful strategy because such tools can inhibit multiple pathways, simultaneously. Nab-Paclitaxel has been shown to target pancreatic cancer CAFs. AMD3100, a CXCL12 chemokine receptor inhibitor, shows improved immune response/immunotherapy response to pancreatic cancer-CXCL12 is secreted by CAFs.

CAFs are critical in the metastatic process. CAFs can travel with cancer cells through the blood stream facilitating survival and extravasation at metastatic sites. Aiello et al. showed that fibroblasts appeared in distant metastases when the metastases were as small as 6-7 cells [78]. They also showed that stromal volume of metastases eventually reaches the same volume as the stroma in the primary tumor [79]. In the case of pancreatic cancer liver metastasis, "CAFs" can also be activated locally. Specifically, pancreatic cancer cell exosomes expressing resident surface integrins are taken up by liver Kupffer cells and subsequently activate hepatic stellate cells. Activated hepatic stellate cells acquire a CAF phenotype and contribute to the production of pro-metastatic hepatic niches. Tumor cells then land in the liver and metastases develop. This may explain the early liver metastases seen in some pancreatic cancer patients [80] (Figure 2). 


\section{Modulation of CAFs to Treat Pancreatic Cancer}

Most strategies to manipulate CAFs to treat cancer focus on either interfering with the function of CAFs as a barrier to effective drug delivery or inhibiting CAF activation. CAFs have been shown to build cage like structures around pancreatic cancer tumor cells making them resistant to chemotherapy [45]. Transforming growth factor-beta modulates pancreatic cancer cell associated fibroblasts shape, stiffness, and invasion involved in tumor progression and metastases. Inhibition of TGF-beta inhibits these effects and has been shown to decrease virulence of the pancreatic cancer in some studies [29] (Table 3). Inhibition of signaling pathways that are commonly activated in CAFs, like TGF-beta, hedgehog, or the angiotensin II receptor, have been shown to promote a reduction in CAFs, extracellular matrix and a potentiation of drug delivery to tumor. This strategy has inhibited tumor growth and metastases in various pre-clinical studies. A landmark study by Olive et al. showed that depletion of tumor stroma using the hedgehog inhibitor IPI-926 resulted in enhanced gemcitabine-induced intra-tumoral drug accumulation and efficacy in pancreatic cancer [81]. However, subsequent studies including a trial in humans did not show similar positive results $[82,83]$. Inhibition of CAF-induced pro-tumorigenic signals may be a highly attractive strategy to improve anti-cancer therapy in pancreatic cancer. Researchers have shown that inhibition of the MTOR pathway in pancreas CAFs using the somatostatin analogue SOM230 resulted in reduced CAF mediated secretion of IL-6, a cytokine that stimulates chemoresistance [40]. Importantly, the use of mTOR inhibition potentiated drug sensitivity of the pancreas tumor [40]. It also inhibited CAF-mediated exocrine secretion of IL-6 [40].

Table 3. Anti-CAF treatment strategies and results in experimental models.

\begin{tabular}{|c|c|c|}
\hline Treatment & Result & Reference \\
\hline Depletion of CAF-derived annexin (67) & $\begin{array}{l}\text { Impaired tumor cell survival and } \\
\text { migration in mouse model }\end{array}$ & Leca et al., J Clin Invest, 2016 [30] \\
\hline Depletion of Big-h3 & $\begin{array}{l}\text { Reduction of pancreatic tumor growth by } \\
\text { functionally reprogramming F } 4 / 80 \\
\text { macrophages in tumor environment }\end{array}$ & Goehrig et al., Gut, 2019. [37] \\
\hline $\begin{array}{l}\text { Treatment with Nutilin-3a induces } \\
\text { p53 activation }\end{array}$ & $\begin{array}{l}\text { Induces p53 activation in the stroma, } \\
\text { reverses activation of pancreatic stellate } \\
\text { cells, and decreases stromal fibrosis }\end{array}$ & $\begin{array}{l}\text { Saison-Ridinger et al.m PLoS One, } \\
2017 \text { [85] }\end{array}$ \\
\hline $\begin{array}{l}\text { miRNA therapies that target } \mathrm{ZEB} \text { and its } \\
\text { downstream pathway }\end{array}$ & $\begin{array}{l}\text { Strategy to improve outcome by } \\
\text { inhibiting multiple gene pathways }\end{array}$ & Bronsert et al., Surgery, 2014 [67] \\
\hline PEGPH20 (digests hyaluronic acid) & $\begin{array}{l}\text { Improves delivery of immuno- and } \\
\text { chemotherapy to the tumor }\end{array}$ & $\begin{array}{l}\text { Wong et al., Curr Oncol Rep, } 2017 \text { [87] } \\
\text { Clinical trials ongoing }\end{array}$ \\
\hline Galunisertib (TGFB-1 inhibition) & $\begin{array}{l}\text { Inhibits TGFB- } 1 \text { receptor, found to show } \\
\text { improved overall survival in combination } \\
\text { with gemcitabine versus } \\
\text { gemcitabine alone. }\end{array}$ & $\begin{array}{l}\text { Melisi, Br J Cancer, } 2018 \text { [88] } \\
\text { Clinical trials ongoing }\end{array}$ \\
\hline $\begin{array}{l}\text { Depletion of ANXA6 extracellular vesicles } \\
\text { in CAFs }\end{array}$ & $\begin{array}{l}\text { Impaired pancreas cancer migration } \\
\text { and invasion. }\end{array}$ & Leca et al., J Clin Invest, 2016 [30] \\
\hline
\end{tabular}

Targeting stromal components and stromal depletion has become an area of exciting research in pancreatic cancer (Table 3). Stromally derived lysyl oxidase (LOX) is involved in collagen cross linking 
and strengthening the collagen matrix. Small molecule LOX inhibitors reduced angiogenesis and growth in experimental breast cancer and led to decreased metastases in lung and liver [90]. In another experimental model of breast cancer, inhibition of LOX activity had no effect on tumor latency and size but significantly decreased tumor metastatis by inhibition of tumor cell extravasation [91]. Thus, inhibition of LOX may be an important potential strategy to inhibit metastasis of cancer. Focal adhesion kinase (FAK) is increased in neoplastic pancreatic cancer cells as well as CAFs [60,92]. It is associated with fibrosis and poor CD8+ T cell infiltration. The selective FAK inhibitor VS-4718 resulted in reduced pancreatic cancer fibrosis and decreased numbers of cytotoxic T cells in a KPC mouse model of pancreas cancer. Treatment with the inhibitor resulted in a doubling of survival and made the mouse model more responsive to T cell immunotherapy and PD-1 antagonists [93]. FAK inhibition also decreased lymph node metastases in a mouse melanoma model by blocking vascular cell adhesion molecule (VCAM-1) [94]. Targeting components of the tumor stroma like fibronectin in pancreatic cancer can effectively reduce tumor growth and spread while enhancing anti-tumor drug delivery [95]. The presence of cancer cellular and stomal fibronectin is necessary for pancreatic cancer progression. Endothelial monocyte activation polypeptide 11 (EMAP II) interferes with fibronectin-integrin angiogenesis signaling in pancreatic cancer. EMAP II caused a significant reduction in tumor growth with a decrease in microvessel density and proliferative activity in a heterotopic pancreatic cancer model. The anti-tumor activity of EMAP II is mediated through targeted interference with stroma fibronectin-integrin dependent pancreatic cancer cell proliferation [96]. New findings indicate that the depletion of fibronectin switches the activity of secreted protein acidic cysteine-rich (SPARC) from promoting cancer cell proliferation to growth inhibition and induction of apoptosis [97].

SPARC is highly expressed in tumor stroma principally in peritumoral fibroblasts. Overexpression of SPARC in this compartment is associated with poorer prognosis. SPARC is involved in angiogenesis, apoptosis, invasion and adhesion, cell cycle progression, and proliferation [86]. SPARC and hyaluronan synthetase are targets of ETV1 that result in stromal expansion. Overexpression of ETV1 increased the incidence and volume of metastases in mouse models. SPARC deletion has been shown to completely abrogate the pro-tumorigenic effects of ETV1 overexpression supporting the pathway link $[5,98]$. Neuregulin (NRG1) 1, a ligand for HER3 and HER4 receptors, is secreted by both pancreatic cancer cells and CAFs. The desmoplastic stroma adds to pancreatic cancer aggressiveness by promoting tumor progression, invasion, and resistance to chemotherapy. 7E3, an original antibody to NRG1 promotes antibody dependent cellular toxicity in NRG-1+ pancreatic cancer cells and CAFs. It inhibits migration and growth of pancreatic cancer cells that are co-cultured with CAFs both in experimental models of pancreatic cancer. Studies shows that 7E3 could be a promising antibody mediated approach to targeting the relationship between pancreatic cancer and CAFs [99]. Src kinase expression from fibroblasts supports invasion and metastases of pancreatic cancer. Src expression and activity are up-regulated in pancreatic cancer and correlate with reduced survival. The Src kinase inhibitor dasatinib significantly inhibited the development of metastases and growth of pancreatic cancer in a mouse genetically engineered pancreatic cancer model [100]. CAFs have receptors for platelet derived growth factor (PDGF) and are activated by stimulation of their PDGR-receptor. Upon PDGF stimulation and activation of the PDGF-receptor JAK is phosphorylated and further activates STAT3 a transcription factor that is translocated into the nucleus where it promotes the transcription of genes responsible for cell growth, differentiation, proliferation, and apoptosis. The tyrosine kinase receptor antagonist ruxolitinib can inhibit JAK and prevent STAT-3 activation and thus inhibit tumor growth and increase apoptosis of tumor cells [101].

Although the majority of studies suggest that CAFs support tumor progression rather than restraining it, there is still some controversy about whether CAFs are actually good or bad. CAFs form a tumor stromal capsule that may either protect the tumor from adversarial elements like chemotherapy or immunotherapy, but conversely the capsule may inhibit tumor growth. Some studies have shown that depletion of CAFs has induced less differentiated and ultimately more aggressive tumors [20]. 
Transgenic mice with the ability to delete alpha-SMA myofibroblasts were generated. Depletion of these fibroblasts at either the PanIN or pancreatic cancer stage led to invasive cancerous tumors with EMT and diminished mouse survival. Further, in human pancreatic cancer patients reduced numbers of myofibroblasts in the tumor correlated with reduced survival [20]. Sonic hedgehog (Shh), a soluble ligand overexpressed by pancreatic adenocarcinoma cells, drives formation of fibroblast-rich desmoplastic stroma. Deletion of Shh in a murine model of pancreatic cancer resulted in reduced stromal content of tumor, but unexpectedly, these tumors were more aggressive and had more vascularity, increased proliferation, and undifferentiated histology. Shh deficient tumors could be treated by VEGFR blocking antibody resulting in less tumor angiogenesis and improved survival [22]. Recent studies in mouse models of pancreatic cancer suggest that there may be two functionally different populations of CAFs. One that promotes the tumor and the other that opposes it. A recent study suggests that Meflin, a glycosylphosphatidylinositol-anchored protein that serves as a marker of mesenchymal/stromal cells. In a large number of human pancreatic cancer tissues infiltration by Meflin-positive CAFs correlated with favorable patient outcome. In a mouse model, Meflin deficiency led to tumor progression and poorly differentiated tumors [102]. Expression of Meflin in CAFs may be a method to distinguish a favorable CAF from a detrimental one. This has not yet been elucidated.

In one mouse study, gentle, less complete depletion of CAFs using a biological substance named curcumin that changes CAFs back to a more normal state rather than indiscriminate near complete depletion suppressed CAF-induced pancreatic cancer cell migration and invasion in vitro and lung metastases in vivo [103]. These results indicate possible tumor-suppressive effects of the CAFs in the stroma and indicate that effective anti-CAF therapies in pancreatic cancer will likely need to modify CAFs rather than ablate them entirely. miRNAs, small endogenous non-protein encoding RNAs, are capable of regulating many cellular processes by inhibiting hundreds of genes simultaneously. As such, they may be interesting molecules to modulate the CAF phenotype. Reversal of up regulated or down regulated miRNAs in CAFs using anti-miRNA or mimetic oligonucleotides can result in a non-CAF phenotype. A recent study in pancreatic cancer showed that miR-199a and miR-214 were upregulated in a patient-derived CAFs and that inhibition of these miRNAs caused the dedifferentiation of activated pancreatic stellate cells and inhibited tumor promoting paracrine effects [104]. Another factor to consider is differences in CAF subpopulations, some of which may specifically be tumor-promoting while others are tumor-inhibiting. Current studies must aim to distinguish different sub-types of CAFs such that we can therapeutically affect the detrimental pro-tumoral CAFs types while supporting the anti-tumor ones [5].

CAF effects on tumor immune cells may help to explain their seemingly paradoxical role in pancreas tumors, and these relationships are currently active areas of investigation. The stromal protein Big-h3 is a key factor in the immune paracrine interaction that drives pancreatic cancer. It is produced by CAFs in the stroma of pancreatic cancer. It acts directly on CD8+ T cells and F4/80 macrophages to inhibit the immune anti-tumor response to the pancreatic cancer. Depleting Big-h3 in vivo in mice reduced tumor growth by increasing the number of CD8+ T cells and F4/80 macrophages [37]. Targeting stroma in a murine model of metastatic pancreatic cancer using the immune modulating effect of hyaluronan degradation by PEGPH20 significantly decreased the immunosuppressive effect of CXCL12/CXCR4/CCR7 signaling axis in CAFs, myeloid, and CD8+ T cells. This also resulted in increased CCR7(-) effector memory $\mathrm{T}$ cell infiltration, increased interferon-gamma secretion, and increased numbers of CD8+ T cells and most importantly improved survival in an animal model of metastatic pancreatic cancer [105]. Stromal modulation has also shown promising results in the enhancement of immune checkpoint blockade treatment for pancreatic cancer. Inhibiting CXCL12 produced by FAP+ CAFs re-sensitizes pancreatic cancer cells to anti-PDL1 immunotherapy [31]. Effective stromal modulation was recently reported by a polymeric micelle-based nano formulation to deliver a sonic hedgehog inhibitor cyclopamine (CPA) combined with a cytotoxic chemotherapy drug paclitaxel. This combination modulated pancreatic cancer stroma by increasing intra-tumoral vascular density. It then promoted tumor infiltration by cytotoxic CD8+ T cells and when checkpoint 
blockade with PD-1 was added to this combination prolonged survival in mouse models of pancreatic cancer [89].

\section{Conclusions}

Pancreatic cancer CAFs represent an exciting area of research and many excellent preliminary studies suggest that this will be an important area for anti-tumor therapy. Our understanding of the heterogeneity, activation, and roles of pancreas CAFs needs to improve in order to maximize their potential for therapeutic benefit. Because there is convincing evidence for the heterogeneity of CAFs in pancreas tumors and sub-populations with differing functions, it will be necessary to target specific CAF subsets to achieve clinically relevant anti-cancer effects. This means that we will need to better identify specific CAF targets. It may also be possible to therapeutically target CAFs in metastases, since they are known to play an important role in this context. The future is to target specific subgroups to produce the anti-tumor effects needed either in concert with chemotherapy or the immune system. This may be an effective strategy to increase the cure-rate in patients with pancreatic cancer.

Funding: This research is supported by a grant from Emerson Collective.

Conflicts of Interest: The authors declare no conflict of interest.

\section{References}

1. American Cancer Society. Cancer Facts and Figures 2019; ACS Publications: Washington, DC, USA, 2019.

2. Evan, G.I.; Hah, N.; Littlewood, T.D.; Sodir, N.M.; Campos, T.; Downes, M.; Evans, R.M. Re-engineering the Pancreas Tumor Microenvironment: A “Regenerative Program” Hacked. Clin. Cancer Res. 2017, 23, 1647-1655. [CrossRef]

3. Waghray, M.; Yalamanchili, M.; di Magliano, M.; Simone, D. Deciphering the role of stroma in pancreatic cancer. Curr. Opin. Gastroenterol. 2013, 29, 537-543. [CrossRef]

4. Vennin, C.; Murphy, K.J.; Morton, J.P.; Cox, T.R.; Pajic, M.; Timpson, P. Reshaping the tumor stroma for the treatment of pancreatic cancer. Gastroenterology 2018, 152, 820-838. [CrossRef]

5. Von Ahrens, D.; Bhagat, T.D.; Nagrath, D.; Maitra, A.; Verma, A. The role of stromal cancer-associated fibroblasts in pancreatic cancer. J. Hematol. Oncol. 2017, 10, 76. [CrossRef]

6. Brabletz, T. To differentiate or not-routes towards metastasis. Nat. Rev. Cancer 2012, 12, 425-436. [CrossRef]

7. Lapshyn, H.; Bolm, L.; Kohler, I.; Werner, M.; Billmann, F.G.; Bausch, D.; Hopt, U.T.; Makowiec, F.; Wittel, U.A.; Keck, T.; et al. Histopathological tumor invasion of the mesenterico-portal vein is characterized by aggressive biology and stromal fibroblast activation. HPB Oxford 2017, 19, 67-74. [CrossRef]

8. Sherman, M.H. Stellate Cells in Tissue Repair, Inflammation, and Cancer. Annu. Rev. Cell Dev. Biol. 2018, 34, 333-355. [CrossRef]

9. Sherman, M.H.; Yu, R.T.; Tseng, T.W.; Sousa, C.M.; Liu, S.; Truitt, M.L.; He, N.; Ding, N.; Liddle, C.; Atkins, A.R.; et al. Stromal cues regulate the pancreatic cancer epigenome and metabolome. Proc. Natl. Acad. Sci. USA 2017, 114, 1129-1134. [CrossRef]

10. Ansari, D.; Carvajo, M.; Bauden, M.; Andersson, R. Pancreatic cancer stroma: Controversies and current insights. Scand. J. Gastroenterol. 2017, 52, 641-646. [CrossRef]

11. Chang, H.Y.; Sneddon, J.B.; Alizadeh, A.A.; Sood, R.; West, R.B.; Montgomery, K.; Chi, J.T.; van de Rijn, M.; Botstein, D.; Brown, P.O. Gene expression signature of fibroblast serum response predicts human cancer progression: Similarities between tumors and wounds. PLoS Biol. 2004, 2, E7. [CrossRef]

12. Chang, H.Y.; Chi, J.T.; Dudoit, S.; Bondre, C.; van de Rijn, M.; Botstein, D.; Brown, P.O. Diversity, topographic differentiation, and positional memory in human fibroblasts. Proc. Natl. Acad. Sci. USA 2002, 99, 12877-12882. [CrossRef]

13. Neesse, A.; Bauer, C.A.; Ohlund, D.; Lauth, M.; Buchholz, M.; Michl, P.; Tuveson, D.A.; Gress, T.M. Stromal biology and therapy in pancreatic cancer: Ready for clinical translation. GUT 2019, 68, 159-171. [CrossRef]

14. Yin, Z.; Dong, C.; Jiang, K.; Xu, Z.; Li, R.; Guo, K.; Shao, S.; Wang, L. Heterogeneity of cancer-associated fibroblasts and roles in the progression, prognosis, and therapy of hepatocellular carcinoma. J. Hematol. Oncol. 2019, 12, 101. [CrossRef] 
15. Heinrich, S.; Besselink, M.; Moehler, M.; van Laethem, J.L.; Ducreux, M.; Grimminger, P.; Mittler, J.; Lang, H.; Lutz, M.P.; Lesurtel, M.; et al. Opinions and use of neoadjuvant therapy for resectable, borderline resectable, and locally advanced pancreatic cancer: International survey and case-vignette study. BMC Cancer 2019, 19, 675. [CrossRef]

16. Alvarez, R.; Musteanu, M.; Garcia-Garcia, E.; Lopez-Casas, P.P.; Megias, D.; Guerra, C.; Munoz, M.; Quijano, Y.; Cubillo, A.; Rodriguez-Pascual, J.; et al. Stromal disrupting effects of nab-paclitaxel in pancreatic cancer. Br. J. Cancer 2013, 109, 926-933. [CrossRef]

17. Okada, K.; Kawai, M.; Hirono, S.; Satoi, S.; Yanagimoto, H.; Ioka, T.; Miyazawa, M.; Shimizu, A.; Kitahata, Y.; Yamaue, H. Impact of treatment duration of neoadjuvant FIRINOX in patients with borderline resectable pancreatic cancer: A pilot trial. Cancer Chemother. Pharmacol. 2016, 78, 719-726. [CrossRef]

18. Xu, X.; Wu, Q.; Wang, Z.; Zheng, S.; Ge, K.; Jia, C. Meta-analysis of FOLFIRINOX regimen as the first-line chemotherapy for locally advanced pancreatic cancer and borderline resectable pancvreatic cancer. Clin. Exp. Med. 2018, 19, 149-157. [CrossRef]

19. Sahai, E.; Astsaturov, I.; Cukierman, E.; DeNardo, D.G.; Egeblad, M.; Evans, R.M.; Fearon, D.; Greten, F.R.; Hingorani, S.R.; Hunter, T.; et al. A framework for advancing our understanding of cancer-associated fibroblasts. Nat. Rev. Cancer 2020, 20, 174-186. [CrossRef]

20. Özdemir, B.C.; Pentcheva-Hoang, T.; Carstens, J.L.; Zheng, X.; Wu, C.C.; Simpson, T.; Laklai, H.; Sugimoto, H.; Kahlert, C.; Novitskiy, S.V.; et al. Depletion of Carcinoma-Associated Fibroblasts and Fibrosis Induces Immunosuppression and Accelerates Pancreas Cancer with Diminished Survival. Cancer Cell 2014, 25, 719-734. [CrossRef]

21. Catenacci, D.V.; Junttila, M.R.; Karrison, T.; Bahary, N.; Horiba, M.N.; Nattam, S.R.; Marsh, R.; Wallace, J.; Kozloff, M.; Rajdev, L.; et al. Randomized Phase Ib/II Study of Gemcitabine Plus Placebo or Vismodegib, a Hedgehog Pathway Inhibitor, in Patients With Metastatic Pancreatic Cancer. J. Clin. Oncol. 2015, 33, 4284-4292. [CrossRef]

22. Rhim, A.D.; Oberstein, P.E.; Thomas, D.H.; Mirek, E.T.; Palermo, C.F.; Sastra, S.A.; Dekleva, E.N.; Saunders, T.; Becerra, C.P.; Tattersall, I.W.; et al. Stromal elements act to restrain, rather than support, pancreatic ductal adenocarcinoma. Cancer Cell 2014, 25, 735-747. [CrossRef]

23. Sun, Q.; Zhang, B.; Hu, Q.; Qin, Y.; Xu, W.; Liu, W.; Yu, X.; Xu, J. The impact of cancer-associated fibroblasts on major hallmarks of pancreatic cancer. Theranostics 2018, 8, 5072-5087. [CrossRef]

24. Lafero, K.J.; Melstrom, L.G. The paradixical web of pancreatic cancer tumor microenvironment. Am. J. Pathol. 2019, 189, 44-57. [CrossRef]

25. Liu, T.; Han, C.; Wang, S.; Fang, P.; Ma, Z.; Xu, L.; Yin, R. Cancer-associated fibroblasts: An emerging target of anti-cancer immunotherapy. J. Hematol. Oncol. 2019, 12, 15-86. [CrossRef]

26. Park, D.; Sahai, E.; Rullan, A. SnapShot: Cancer-Associated Fibroblasts. Cell 2020, 181, 481-486. [CrossRef]

27. Prakash, J. Cancer-Associated Fibroblasts: Perspective in Cancer Therapy. Trends Cancer 2016, 2, $277-279$. [CrossRef]

28. Biffi, G.; Tuveson, D.A. Deciphering cancer fibroblasts. J. Exp. Med. 2018, 215, 2967-2968. [CrossRef]

29. Stylianou, A.; Gkretsi, V.; Stylianopoulos, T. Transforming growth factor-beta modulates pancreatic cancer associated fibroblasts cell shape, stiffness and invasion. Biochim. Biophys. Acta Gen. Subj. 2018, 1862, 1537-1546. [CrossRef]

30. Leca, J.; Martinez, S.; Lac, S.; Nigri, J.; Secq, V.; Rubis, M.; Bressy, C.; Serge, A.; Lavaut, M.N.; Dusetti, N.; et al. Cancer-associated fibroblast-derived annexin A6+ extracellular vesicles support pancreatic cancer aggressiveness. J. Clin. Investig. 2016, 126, 4140-4156. [CrossRef]

31. Feig, C.; Jones, J.O.; Kraman, M.; Wells, R.J.; Deonarine, A.; Chan, D.S.; Connell, C.M.; Roberts, E.W.; Zhao, Q.; Caballero, O.L.; et al. Targeting CXCL12 from FAP-expressing carcinoma-associated fibroblasts synergizes with anti-PD-L1 immunotherapy in pancreatic cancer. Proc. Natl. Acad. Sci. USA 2013, 110, 20212-20217. [CrossRef]

32. Drifka, C.R.; Loeffler, A.G.; Mathewson, K.; Keikhosravi, A.; Eickhoff, J.C.; Liu, Y.; Weber, S.M.; Kao, W.J.; Eliceiri, K.W. Highly aligned stromal collagen is a negative prognostic factor following pancreatic ductal adenocarcinoma resection. Oncotarget 2016, 7, 76197-76213. [CrossRef]

33. Wang, L.; Wu, H.; Wang, L.; Zhang, H.; Lu, J.; Liang, Z.; Liu, T. Asporin promotes pancreatic cancer cell invasion and migration by regulating the epithelial-to-mesenchymal transition (EMT) through both autocrine and paracrine mechanisms. Cancer Lett. 2017, 398, 24-36. [CrossRef] 
34. Ahmadzadeh, M.; Rosenberg, S.A. TGF-beta 1 attenuates the acquisition and expression of effector function by tumor antigen-specific human memory CD8 T cells. J. Immunol. 2005, 174, 5215-5223. [CrossRef]

35. Ligorio, M.; Sil, S.; Malagon-Lopez, J.; Nieman, L.T.; Misale, S.; Di Pilato, M.; Ebright, R.Y.; Karabacak, M.N.; Kulkarni, A.S.; Liu, A.; et al. Stromal Microenvironment Shapes the Intratumoral Architecture of Pancreatic Cancer. Cell 2019, 178, 160-175. [CrossRef]

36. Wang, T.; Notta, F.; Navab, R.; Joseph, J.; Ibrahimov, E.; Xu, J.; Zhu, C.Q.; Borgida, A.; Gallinger, S.; Tsao, M.S. Senescent Carcinoma-Associated Fibroblasts Upregulate IL8 to Enhance Prometastatic Phenotypes. Mol. Cancer Res. 2017, 15, 3-14. [CrossRef]

37. Goehrig, D.; Nigri, J.; Samain, R.; Wu, Z.; Cappello, P.; Gabiane, G.; Zhang, X.; Zhao, Y.; Kim, I.S.; Chanal, M.; et al. Stromal protein betaig-h3 reprogrammes tumour microenvironment in pancreatic cancer. Gut 2019, 68, 693-707. [CrossRef]

38. Kawase, T.; Yasui, Y.; Nishina, S.; Hara, Y.; Yanatori, I.; Tomiyama, Y.; Nakashima, Y.; Yoshida, K.; Kishi, F.; Nakamura, M.; et al. Fibroblast activation protein-alpha-expressing fibroblasts promote the progression of pancreatic ductal adenocarcinoma. BMC Gastroenterol. 2015, 15, 109. [CrossRef]

39. Hu, G.; Wang, S.; Xu, F.; Ding, Q.; Chen, W.; Zhong, K.; Huang, L.; Xu, Q. Tumor-Infiltrating Podoplanin+ Fibroblasts Predict Worse Outcome in Solid Tumors. Cell Physiol. Biochem. 2018, 51, 1041-1050. [CrossRef]

40. Duluc, C.; Moatassim-Billah, S.; Chalabi-Dchar, M.; Perraud, A.; Samain, R.; Breibach, F.; Gayral, M.; Cordelier, P.; Delisle, M.B.; Bousquet-Dubouch, M.P.; et al. Pharmacological targeting of the protein synthesis $\mathrm{mTOR} / 4 \mathrm{E}-\mathrm{BP} 1$ pathway in cancer-associated fibroblasts abrogates pancreatic tumour chemoresistance. EMBO Mol. Med. 2015, 7, 735-753. [CrossRef]

41. Masamune, A.; Kikuta, K.; Watanabe, T.; Satoh, K.; Hirota, M.; Shimosegawa, T. Hypoxia stimulates pancreatic stellate cells to induce fibrosis and angiogenesis in pancreatic cancer. Am. J. Physiol. Gastrointest. Liver Physiol. 2008, 295, G709-G717. [CrossRef]

42. Wei, L.; Ye, H.; Li, G.; Lu, Y.; Zhou, Q.; Zheng, S.; Lin, Q.; Liu, Y.; Li, Z.; Chen, R. Cancer-associated fibroblasts promote progression and gemcitabine resistance via the SDF-1/SATB-1 pathway in pancreatic cancer. Cell Death Dis. 2018, 9, 1065. [CrossRef] [PubMed]

43. Brunetto, E.; De Monte, L.; Balzano, G.; Camisa, B.; Laino, V.; Riba, M.; Heltai, S.; Bianchi, M.; Bordignon, C.; Falconi, M.; et al. The IL-1/IL-1 receptor axis and tumor cell released inflammasome adaptor ASC are key regulators of TSLP secretion by cancer associated fibroblasts in pancreatic cancer. J. Immunother. Cancer 2019, 7, 45. [CrossRef]

44. Conklin, M.W.; Eickhoff, J.C.; Riching, K.M.; Pehlke, C.A.; Eliceiri, K.W.; Provenzano, P.P.; Friedl, A.; Keely, P.J. Aligned collagen is a prognostic signature for survival in human breast carcinoma. Am. J. Pathol. 2011, 178, 1221-1232. [CrossRef]

45. Neumann, C.C.M.; von Horschelmann, E.; Reutzel-Selke, A.; Seidel, E.; Sauer, I.M.; Pratschke, J.; Bahra, M.; Schmuck, R.B. Tumor-stromal cross-talk modulating the therapeutic response in pancreatic cancer. Hepatobil. Pancreat. Dis. Int. 2018, 17, 461-472. [CrossRef]

46. Mahdavi, V.; Hynes, R.O. Effects of cocultivation with transformed cells on surface proteins of normal cells. Biochim. Biophys. Acta 1978, 542, 191-208. [CrossRef]

47. Biffi, G.; Oni, T.E.; Spielman, B.; Hao, Y.; Elyada, E.; Park, Y.; Preall, J.; Tuveson, D.A. IL1-Induced JAK/STAT Signaling Is Antagonized by TGFbeta to Shape CAF Heterogeneity in Pancreatic Ductal Adenocarcinoma. Cancer Discov. 2019, 9, 282-301. [CrossRef]

48. Ohlund, D.; Handly-Santana, A.; Biffi, G.; Elyada, E.; Almeida, A.S.; Ponz-Sarvise, M.; Corbo, V.; Oni, T.E.; Hearn, S.A.; Lee, E.J.; et al. Distinct populations of inflammatory fibroblasts and myofibroblasts in pancreatic cancer. J. Exp. Med. 2017, 214, 579-596. [CrossRef]

49. Nielsen, M.F.B.; Mortensen, M.B.; Detlefsen, S. Typing of pancreatic cancer-associated fibroblasts identifies different subpopulations. World J. Gastroenterol. 2018, 24, 4663-4678. [CrossRef]

50. Neuzillet, C.; Tijeras-Raballand, A.; Ragulan, C.; Cros, J.; Patil, Y.; Martinet, M.; Erkan, M.; Kleeff, J.; Wilson, J.; Apte, M.; et al. Inter- and intra-tumoural heterogeneity in cancer-associated fibroblasts of human pancreatic ductal adenocarcinoma. J. Pathol. 2019, 248, 51-65. [CrossRef]

51. Whittle, M.C.; Hingorani, S.R. Fibroblasts in Pancreatic Ductal Adenocarcinoma: Biological Mechanisms and Therapeutic Targets. Gastroenterology 2019, 156, 2085-2096. [CrossRef] 
52. Waghray, M.; Yalamanchili, M.; Dziubinski, M.; Zeinali, M.; Erkkinen, M.; Yang, H.; Schradle, K.A.; Urs, S.; Pasca Di Magliano, M.; Welling, T.H.; et al. GM-CSF Mediates Mesenchymal-Epithelial Cross-talk in Pancreatic Cancer. Cancer Discov. 2016, 6, 886-899. [CrossRef] [PubMed]

53. Gunderson, A.J.; Yamazaki, T.; McCarty, K.; Phillips, M.; Alice, A.; Bambina, S.; Zebertavage, L.; Friedman, D.; Cottam, B.; Newell, P.; et al. Blockade of fibroblast activation protein in combination with radiation treatment in murine models of pancreatic adenocarcinoma. PLoS ONE 2019, 14, e0211117. [CrossRef] [PubMed]

54. Wormann, S.M.; Song, L.; Ai, J.; Diakopoulos, K.N.; Kurkowski, M.U.; Gorgulu, K.; Ruess, D.; Campbell, A.; Doglioni, C.; Jodrell, D.; et al. Loss of P53 Function Activates JAK2-STAT3 Signaling to Promote Pancreatic Tumor Growth, Stroma Modification, and Gemcitabine Resistance in Mice and Is Associated With Patient Survival. Gastroenterology 2016, 151, 180-193. [CrossRef] [PubMed]

55. Zhao, J.; Wang, H.; Hsiao, C.H.; Chow, D.S.; Koay, E.J.; Kang, Y.; Wen, X.; Huang, Q.; Ma, Y.; Bankson, J.A.; et al. Simultaneous inhibition of hedgehog signaling and tumor proliferation remodels stroma and enhances pancreatic cancer therapy. Biomaterials 2018, 159, 215-228. [CrossRef] [PubMed]

56. Hirakawa, T.; Yashiro, M.; Doi, Y.; Kinoshita, H.; Morisaki, T.; Fukuoka, T.; Hasegawa, T.; Kimura, K.; Amano, R.; Hirakawa, K. Pancreatic Fibroblasts Stimulate the Motility of Pancreatic Cancer Cells through IGF1/IGF1R Signaling under Hypoxia. PLoS ONE 2016, 11, e0159912. [CrossRef]

57. Tjomsland, V.; Niklasson, L.; Sandstrom, P.; Borch, K.; Druid, H.; Bratthall, C.; Messmer, D.; Larsson, M.; Spangeus, A. The desmoplastic stroma plays an essential role in the accumulation and modulation of infiltrated immune cells in pancreatic adenocarcinoma. Clin. Dev. Immunol. 2011, 2011, 212810. [CrossRef]

58. Crawford, H.C.; Pasca di Magliano, M.; Banerjee, S. Signaling Networks That Control Cellular Plasticity in Pancreatic Tumorigenesis, Progression, and Metastasis. Gastroenterology 2019, 156, 2073-2084. [CrossRef]

59. Tjomsland, V.; Spangeus, A.; Valila, J.; Sandstrom, P.; Borch, K.; Druid, H.; Falkmer, S.; Falkmer, U.; Messmer, D.; Larsson, M. Interleukin 1alpha sustains the expression of inflammatory factors in human pancreatic cancer microenvironment by targeting cancer-associated fibroblasts. Neoplasia 2011, 13, 664-675. [CrossRef]

60. Begum, A.; McMillan, R.H.; Chang, Y.T.; Penchev, V.R.; Rajeshkumar, N.V.; Maitra, A.; Goggins, M.G.; Eshelman, J.R.; Wolfgang, C.L.; Rasheed, Z.A.; et al. Direct Interactions With Cancer-Associated Fibroblasts Lead to Enhanced Pancreatic Cancer Stem Cell Function. Pancreas 2019, 48, 329-334. [CrossRef]

61. Brennen, W.N.; Isaacs, J.T.; Denmeade, S.R. Rationale Behind Targeting Fibroblast Activation Protein-Expressing Carcinoma-Associated Fibroblasts as a Novel Chemotherapeutic Strategy. Mol. Cancer Ther. 2012, 11, 257-266. [CrossRef]

62. Fearon, D.T. The carcinoma-associated fibroblast expressing fibroblast activation protein and escape from immune surveillance. Cancer Immunol. Res. 2014, 2, 187-193. [CrossRef] [PubMed]

63. Roulis, M.; Kaklamanos, A.; Schernthanner, M.; Bielecki, P.; Zhao, J.; Kaffe, E.; Frommelt, L.S.; Qu, R.; Knapp, M.S.; Henriques, A.; et al. Paracrine orchestration of intestinal tumorigenesis by a mesenchymal niche. Nature 2020, 580, 524-529. [CrossRef] [PubMed]

64. Elyada, E.; Bolisetty, M.; Laise, P.; Flynn, W.F.; Courtois, E.T.; Burkhart, R.A.; Teinor, J.A.; Belleau, P.; Biffi, G.; Lucito, M.S.; et al. Cross-Species Single-Cell Analysis of Pancreatic Ductal Adenocarcinoma Reveals Antigen-Presenting Cancer-Associated Fibroblasts. Cancer Discov. 2019, 9, 1102-1123. [CrossRef] [PubMed]

65. Zhang, Y.; Ertl, H.C. Depletion of FAP+ cells reduces immunosuppressive cells and improves metabolism and functions CD8+T cells within tumors. Oncotarget 2016, 7, 23282-23299. [CrossRef]

66. Su, S.; Chen, J.; Yao, H.; Liu, J.; Yu, S.; Lao, L.; Wang, M.; Luo, M.; Xing, Y.; Chen, F.; et al. CD10(+)GPR77(+) Cancer-Associated Fibroblasts Promote Cancer Formation and Chemoresistance by Sustaining Cancer Stemness. Cell 2018, 172, 841-856. [CrossRef]

67. Bronsert, P.; Kohler, I.; Timme, S.; Kiefer, S.; Werner, M.; Schilling, O.; Vashist, Y.; Makowiec, F.; Brabletz, T.; Hopt, U.T.; et al. Prognostic significance of Zinc finger E-box binding homeobox 1 (ZEB1) expression in cancer cells and cancer-associated fibroblasts in pancreatic head cancer. Surgery 2014, 156, 97-108. [CrossRef]

68. Halbrook, C.J.; Lyssiotis, C.A. Employing metabolism to improve the diagnosis and treatment of pancreatic cancer. Cancer Cell 2017, 31, 5-19. [CrossRef]

69. Lee, H.M.; Hwang, K.A.; Choi, K.C. Diverse pathways of epithelial mesenchymal transition related with cancer progression and metastasis and potential effects of endocrine disrupting chemicals on epithelial mesenchymal transition process. Mol. Cell Endocrinol. 2017, 457, 103-113. [CrossRef] 
70. Zheng, B.; Ohuchida, K.; Chijiiwa, Y.; Zhao, M.; Mizuuchi, Y.; Cui, L.; Horioka, K.; Ohtsuka, T.; Mizumoto, K.; Oda, Y.; et al. CD146 attenuation in cancer-associated fibroblasts promotes pancreatic cancer progression. Mol. Carcinog. 2016, 55, 1560-1572. [CrossRef]

71. Kadera, B.E.; Li, L.; Toste, P.A.; Wu, N.; Adams, C.; Dawson, D.W.; Donahue, T.R. MicroRNA-21 in pancreatic ductal adenocarcinoma tumor-associated fibroblasts promotes metastasis. PLoS ONE 2013, 8, e71978. [CrossRef]

72. Jones, M.L.; Siddiqui, J.; Pienta, K.J.; Getzenberg, R.H. Circulating fibroblast-like cells in men with metastatic prostate cancer. Prostate 2013, 73, 176-181. [CrossRef] [PubMed]

73. Ao, Z.; Shah, S.H.; Machlin, L.M.; Parajuli, R.; Miller, P.C.; Rawal, S.; Williams, A.J.; Cote, R.J.; Lippman, M.E.; Datar, R.H.; et al. Identification of Cancer-Associated Fibroblasts in Circulating Blood from Patients with Metastatic Breast Cancer. Cancer Res. 2015, 75, 4681-4687. [CrossRef] [PubMed]

74. Duda, D.G.; Duyverman, A.M.; Kohno, M.; Snuderl, M.; Steller, E.J.; Fukumura, D.; Jain, R.K. Malignant cells facilitate lung metastasis by bringing their own soil. Proc. Natl. Acad. Sci. USA 2010, 107, 21677-21682. [CrossRef] [PubMed]

75. Knudsen, E.S.; Balaji, U.; Freinkman, E.; McCue, P.; Witkiewicz, A.K. Unique metabolic features of pancreatic cancer stroma: Relevance to the tumor compartment, prognosis, and invasive potential. Oncotarget 2016, 7, 78396-78411. [CrossRef]

76. Ao, M.; Brewer, B.M.; Yang, L.; Franco Coronel, O.E.; Hayward, S.W.; Webb, D.J.; Li, D. Stretching fibroblasts remodels fibronectin and alters cancer cell migration. Sci. Rep. 2015, 5, 8334. [CrossRef]

77. Lecka, J.; Fausther, M.; Kunzli, B.; Sevigny, J. Ticlopidine in its prodrug form is a selective inhibitor of human NTPDase1. Mediat. Inflamm. 2014, 2014, 1-8. [CrossRef]

78. Aiello, N.; Brabletz, T.; Kang, Y.; Nieto, M.A.; Weinberg, R.A.; Stanger, B.Z. Upholding a role for EMT in pancreatic cancer metastasis. Nature 2017, 547, E7-E8. [CrossRef]

79. Aiello, N.M.; Bajor, D.L.; Norgard, R.J.; Sahmoud, A.; Bhagwat, N.; Pham, M.N.; Cornish, T.C.; Iacobuzio-Donahue, C.A.; Vonderheide, R.H.; Stanger, B.Z. Metastatic progression is associated with dynamic changes in the local microenvironment. Nat. Commun. 2016, 7, 12819. [CrossRef]

80. Costa-Silva, B.; Aiello, N.M.; Ocean, A.J.; Singh, S.; Zhang, H.; Thakur, B.K.; Becker, A.; Hoshino, A.; Mark, M.T.; Molina, H.; et al. Pancreatic cancer exosomes initiate pre-metastatic niche formation in the liver. Nat. Cell Biol. 2015, 17, 816-826. [CrossRef]

81. Olive, K.P.; Jacobetz, M.A.; Davidson, C.J.; Gopinathan, A.; McIntyre, D.; Honess, D.; Madhu, B.; Goldgraben, M.A.; Caldwell, M.E.; Allard, D.; et al. Inhibition of Hedgehog signaling enhances delivery of chemotherapy in a mouse model of pancreatic cancer. Science 2009, 324, 1457-1461. [CrossRef]

82. Ramanathan, R.K.; McDonough, S.L.; Philip, P.A.; Hingorani, S.R.; Lacy, J.; Kortmansky, J.S.; Thumar, J.; Chiorean, E.G.; Shields, A.F.; Behl, D.; et al. Phase IB/II Randomized Study of FOLFIRINOX Plus Pegylated Recombinant Human Hyaluronidase Versus FOLFIRINOX Alone in Patients With Metastatic Pancreatic Adenocarcinoma: SWOG S1313. J. Clin. Oncol. 2019, 37, 1062-1069. [CrossRef]

83. Doherty, G.J.; Tempero, M.; Corrie, P.G. HALO-109-301: A Phase III trial of PEGPH20 (with gemcitabine and nab-paclitaxel) in hyaluronic acid-high stage IV pancreatic cancer. Futur. Oncol. 2018, 14, 13-22. [CrossRef]

84. Mpekris, F.; Papageorgis, P.; Polydorou, C.; Voutouri, C.; Kalli, M.; Pirentis, A.P.; Stylianopoulos, T. Sonic-hedgehog pathway inhibition normalizes desmoplastic tumor microenvironment to improve chemoand nanotherapy. J. Control. Release 2017, 261, 105-112. [CrossRef]

85. Saison-Ridinger, M.; DelGiorno, K.E.; Zhang, T.; Kraus, A.; French, R.; Jaquish, D.; Tsui, C.; Erikson, G.; Spike, B.T.; Shokhirev, M.N.; et al. Reprogramming pancreatic stellate cells via p53 activation: A putative target for pancreatic cancer therapy. PLoS ONE 2017, 12, e0189051. [CrossRef] [PubMed]

86. Vaz, J.; Ansari, D.; Sasor, A.; Andersson, R. SPARC: A Potential Prognostic and Therapeutic Target in Pancreatic Cancer. Pancreas 2015, 44, 1024-1035. [CrossRef] [PubMed]

87. Wong, K.M.; Horton, K.J.; Coveler, A.L.; Hingorani, S.R.; Harris, W.P. Targeting the Tumor Stroma: The Biology and Clinical Development of Pegylated Recombinant Human Hyaluronidase (PEGPH20). Curr. Oncol. Rep. 2017, 19, 47. [CrossRef] [PubMed]

88. Melisi, D.; Garcia-Carbonero, R.; Macarulla, T.; Pezet, D.; Deplanque, G.; Fuchs, M.; Trojan, J.; Oettle, H.; Kozloff, M.; Cleverly, A.; et al. Galunisertib plus gemcitabine vs. gemcitabine for first-line treatment of patients with unresectable pancreatic cancer. Br. J. Cancer 2018, 119, 1208-1214. [CrossRef] 
89. Zhao, J.; Xiao, Z.; Li, T.; Chen, H.; Yuan, Y.; Wang, Y.A.; Hsiao, C.H.; Chow, D.S.; Overwijk, W.W.; Li, C. Stromal Modulation Reverses Primary Resistance to Immune Checkpoint Blockade in Pancreatic Cancer. ACS Nano 2018, 12, 9881-9893. [CrossRef]

90. Chang, J.; Lucas, M.C.; Leonte, L.E.; Garcia-Montolio, M.; Singh, L.B.; Findlay, A.D.; Deodhar, M.; Foot, J.S.; Jarolimek, W.; Timpson, P.; et al. Pre-clinical evaluation of small molecule LOXL2 inhibitors in breast cancer. Oncotarget 2017, 8, 26066-26078. [CrossRef] [PubMed]

91. Pickup, M.W.; Laklai, H.; Acerbi, I.; Owens, P.; Gorska, A.E.; Chytil, A.; Aakre, M.; Weaver, V.M.; Moses, H.L. Stromally Derived Lysyl Oxidase Promotes Metastasis of Transforming Growth Factor- $\beta$ Deficient Mouse Mammary Carcinomas. Cancer Res. 2013, 73, 5336-5346. [CrossRef]

92. Kanteti, R.; Mirzapoiazova, T.; Riehm, J.J.; Dhanasingh, I.; Mambetsariev, B.; Wang, J.; Kulkarni, P.; Kaushik, G.; Seshacharyulu, P.; Ponnusamy, M.P.; et al. Focal adhesion kinase a potential therapeutic target for pancreatic cancer and malignant pleural mesothelioma. Cancer Biol. Ther. 2018, 19, 316-327. [CrossRef] [PubMed]

93. Jiang, H.; Hegde, S.; Knolhoff, B.L.; Zhu, Y.; Herndon, J.M.; Meyer, M.A.; Nywening, T.M.; Hawkins, W.G.; Shapiro, I.M.; Weaver, D.T.; et al. Targeting focal adhesion kinase renders pancreatic cancers responsive to checkpoint immunotherapy. Nat. Med. 2016, 22, 851-860. [CrossRef] [PubMed]

94. Jeong, K.; Murphy, J.M.; Rodriguez, Y.A.R.; Kim, J.S.; Ahn, E.E.; Lim, S.S. FAK inhibition reduces metastasis of alpha4 integrin-expressing melanoma to lymph nodes by targeting lymphatic VCAM-1 expression. Biochem. Biophys. Res. Commun. 2019, 509, 1034-1040. [CrossRef]

95. Topalovski, M.; Brekken, R.A. Matrix control of pancreatic cancer: New insights into fibronectin signaling. Cancer Lett. 2016, 381, 252-258. [CrossRef] [PubMed]

96. Schwarz, R.E.; Awasthi, N.; Konduri, S.; Caldwell, L.; Cafasso, D.; Schwarz, M.A. Antitumor effects of EMAP II against pancreatic cancer through inhibition of fibronectin-dependent proliferation. Cancer Biol. Ther. 2010, 9, 632-639. [CrossRef] [PubMed]

97. Munasinghe, A.; Malik, K.; Mohamedi, F.; Moaraf, S.; Kocher, H.; Jones, L.; Hill, N.J. Fibronectin acts as a molecular switch to determine SPARC function in pancreatic cancer. Cancer Lett. 2020, 477, 88-96. [CrossRef]

98. Heeg, S.; Das, K.K.; Reichert, M.; Bakir, B.; Takano, S.; Caspers, J.; Aiello, N.M.; Wu, K.; Neesse, A.; Maitra, A.; et al. ETS-Transcription Factor ETV1 Regulates Stromal Expansion and Metastasis in Pancreatic Cancer. Gastroenterology 2016, 151, 540-553. [CrossRef]

99. Ogier, C.; Colombo, P.E.; Bousquet, C.; Canterel-Thouennon, L.; Sicard, P.; Garambois, V.; Thomas, G.; Gaborit, N.; Jarlier, M.; Pirot, N.; et al. Targeting the NRG1/HER3 pathway in tumor cells and cancer-associated fibroblasts with an anti-neuregulin 1 antibody inhibits tumor growth in pre-clinical models of pancreatic cancer. Cancer Lett. 2018, 432, 227-236. [CrossRef]

100. Morton, J.P.; Karim, S.A.; Graham, K.; Timpson, P.; Jamieson, N.; Athineos, D.; Doyle, B.; McKay, C.; Heung, M.Y.; Oien, K.A.; et al. Dasatinib inhibits the development of metastases in a mouse model of pancreatic ductal adenocarcinoma. Gastroenterology 2010, 139, 292-303. [CrossRef]

101. Itkin, T.; Gur-Cohen, S.; Spencer, J.A.; Schajnovitz, A.; Ramasamy, S.K.; Kusumbe, A.P.; Ledergor, G.; Jung, Y.; Milo, I.; Poulos, M.G.; et al. Distinct bone marrow blood vessels differentially regulate haematopoiesis. Nature 2016, 532, 323-328. [CrossRef]

102. Mizutani, Y.; Kobayashi, H.; Iida, T.; Asai, N.; Masamune, A.; Hara, A.; Esaki, N.; Ushida, K.; Mii, S.; Shiraki, Y.; et al. Meflin-Positive Cancer-Associated Fibroblasts Inhibit Pancreatic Carcinogenesis. Cancer Res. 2019, 79, 5367-5381. [CrossRef] [PubMed]

103. Qu, C.; Wang, Q.; Meng, Z.; Wang, P. Cancer-Associated Fibroblasts in Pancreatic Cancer: Should They Be Deleted or Reeducated? Integr. Cancer Ther. 2018, 17, 1016-1019. [CrossRef] [PubMed]

104. Kuninty, P.R.; Bojmar, L.; Tjomsland, V.; Larsson, M.; Storm, G.; Ostman, A.; Sandstrom, P.; Prakash, J. MicroRNA-199a and -214 as potential therapeutic targets in pancreatic stellate cells in pancreatic tumor. Oncotarget 2016, 7, 16396-16408. [CrossRef] [PubMed]

105. Blair, A.B.; Kim, V.M.; Muth, S.T.; Saung, M.T.; Lokker, N.; Blouw, B.; Armstrong, T.D.; Jaffee, E.M.; Tsujikawa, T.; Coussens, L.M.; et al. Dissecting the Stromal Signaling and Regulation of Myeloid Cells and Memory Effector T Cells in Pancreatic Cancer. Clin. Cancer Res. 2019, 25, 5351-5363. [CrossRef] [PubMed]

(C) 2020 by the authors. Licensee MDPI, Basel, Switzerland. This article is an open access article distributed under the terms and conditions of the Creative Commons Attribution (CC BY) license (http://creativecommons.org/licenses/by/4.0/). 